\title{
Erratum to: Mercury and Selenium Concentrations in Biofilm, Macroinvertebrates, and Fish Collected in the Yankee Fork of the Salmon River, Idaho, USA, and Their Potential Effects on Fish Health
}

\author{
Darren T. Rhea · Aïda M. Farag • David D. Harper • \\ Elizabeth McConnell $\cdot$ William G. Brumbaugh
}

Published online: 18 December 2012

(C) Springer Science+Business Media New York 2012

\section{Erratum to: Arch Environ Contam Toxicol}

DOI 10.1007/s00244-012-9816-x

The original article unfortunately contained an omission. The author neglected to add the statement of product disclaimer. The missing disclaimer is given below.

Disclaimer: Any use of trade, product, or firm names is for descriptive purposes only and does not imply endorsement by the U.S. Government.

The online version of the original article can be found under doi:10.1007/s00244-012-9816-x.

D. T. Rhea · A. M. Farag $(\bowtie) \cdot$ D. D. Harper

Jackson Field Research Station, Columbia Environmental

Research Center, United States Geological Survey,

Jackson, WY, USA

e-mail: aida_farag@usgs.gov

Present Address:

D. T. Rhea

Wyoming Game and Fish Department, Pinedale, WY, USA

E. McConnell

Fish Health Center, United States Fish and Wildlife Service,

Bozeman, MO, USA

Present Address:

E. McConnell

Headwaters Fish Pathology, LLC, Bozeman, MT, USA

W. G. Brumbaugh

Columbia Environmental Research Center, United States

Geological Survey, Columbia, MO, USA 